Niessen, James P. "Heritage and Repatriation in the History of Habsburg and Hungarian Archives." Hungarian Cultural Studies. e-Journal of the American Hungarian Educators Association, Volume 11 (2018) DOI:

\title{
Heritage and Repatriation in the History of Habsburg and Hungarian Archives
}

\section{James P. Niessen}

\begin{abstract}
Hungary's National Library and National Archives seek to collect, as exhaustively as possible, information sources defined as Hungarica: created by, or about, Hungary or Hungarians. Modern archival practice privileges the principle of provenance (the identity of the author or records creator) in determining what an archive should acquire. The Hungarian government's Mikes Kelemen Program, founded in 2013, builds on earlier efforts for the acquisition of foreign Hungarica publications and manuscripts, defined by the Hungarian identity of the author. But because Hungarians living in the diaspora are not only Hungarian, sensitivity to the heritage and collecting interests of the diaspora host country is recommended.
\end{abstract}

Keywords: libraries, archives, manuscripts, diaspora, provenance

Biography: James P. Niessen is World History Librarian at Rutgers University in New Brunswick, NJ. He earned a $\mathrm{PhD}$ in history from Indiana University with a dissertation on the political and religious history of Transylvania in the nineteenth century. He taught history in higher educational institutions for several years, then completed a library degree and has worked as a librarian since 1994. His publications include studies of national movements, church history, library and archival history, and most recently the history of the Hungarian refugee crisis of 1956-57. He served as President of AHEA from 2014 to 2018. niessen@rutgers.edu

The Hungarian government has convened the Diaspora Council in Budapest every fall since 2011 to discuss government programs in support of Hungarian communities living outside the Carpathian Basin. The leaders of diaspora organizations are invited and the government pays their travel and accommodations for the length of the meeting. I attended several of these meetings during my two terms as president of the AHEA from 2014 to 2018. Delegates arriving at the formal meeting receive in their folders an agenda, a list of participants - and the text of the concluding zárónyilatkozat ['closing declaration'] that is approved by signing a sheet that is passed around at the end of the day. At the meetings I attended, additions to the declaration have been made, but never deletions, and I never heard of any dissent from the approval vote. After the Council's declaration in 2013, the Hungarian government created the Mikes Kelemen Program (MKP) for the preservation of otherwise endangered diaspora collections of Hungarica

\footnotetext{
* This article is a revised version of the report presented as a conference paper at the annual conference of AHEA in Toronto, Canada on May 28, 2017.
}

$(\mathrm{cc}) \mathrm{BY}$ ULLS D-Sente 
Niessen, James P. "Heritage and Repatriation in the History of Habsburg and Hungarian Archives." Hungarian Cultural Studies. e-Journal of the American Hungarian Educators Association, Volume 11 (2018) DOI:

(defined as information resources appearing in Hungary, or created by Hungarians, or about Hungary and Hungarians) books and manuscripts by shipping the donated collections to Hungary. Council delegates represent a large range of organizations and occupations, with many scouts, dancers, clergymen, and businessmen but very few from the world of scholarship. AHEA's representation in the Diaspora Council creates an opportunity and responsibility to pay attention to initiatives like the MKP that concern research collections. The statement of purpose on the AHEA website states (ahea.net): "As a heritage organization the AHEA is vitally interested in the preservation of historical documents and artifacts as close as possible to their place of creation."

There are three basic rationales for the MKP. First, it seeks the preservation of Hungarian language collections of private individuals that are in danger of being orphaned and lost because their descendants no longer speak the language, are less interested in Hungarian history and literature, and ethnic organizations have declining capacity or will to accept these collections. Indeed, the diaspora population is aging and there is a declining interest in heritage resources and Hungarian language abilities of the younger generation. Many ethnic organizations are in a difficult financial condition. For example, the American Hungarian Foundation in New Brunswick has an important collection but a small staff and a facility it is struggling to maintain.

Second, publications that might otherwise be lost are vital to the mission of the Országos Széchényi Könyvtár or OSzK ['Széchényi National Library'] as the national library of the Hungarians strives for as complete a collection of Hungarica collections as possible. The vast majority of the publications collected by the MKP and shipped to Hungary (principally from North America and Australia) are Hungarica published in Hungary. The OSzK manages the sorting of the materials after they arrive in Hungary, searches them against the OSzK catalog and keeps what it doesn't have, then distributes the remainder to interested libraries that claim them from online offering lists on the OSzK website. It is estimated that in the first years of the program $90 \%$ of the publications duplicated publications already held by the OSzK, but $10 \%$ did not. Of the remaining 90\%, three-quarters were claimed. This was for the OSzK a very positive result (Dányi 2016: 12-13). The first two volumes of a pamphlet series entitled Hazatérö emlékeink ['Our Cultural Artifacts Returning Home'] were distributed at Diaspora Council sessions in 2016 and 2017 (Gárdonyi, ed. 2016, 2017). These pamphlets provide very interesting descriptions of the procedures and acquisitions of the MKP, both with regard to publications and to manuscript collection. The pamphlets were previously available online at

www.nemzetiregiszter.hu, but as I am revising this report in May 2018 they are no longer online on that site.

Most of the publications removed from North America by the MKP are already held in multiple copies by at the member libraries of OCLC-WorldCat. The interlibrary loan system provides adequate access for most researchers and the benefit of processing such potential donations here in North America does not seem to justify the amount of work involved in shipping, sorting, cataloging, and storing them.

The third rationale for the MKP is that manuscript collections may also be in danger of being lost and the MKP seeks to rescue and "repatriate" these collections to the extent that they are offered for donation. These are unique materials that may have been created in Hungary, but may also include documentation created in North America that document the life of Hungarians who have chosen to live in their new country of residence. 
Niessen, James P. "Heritage and Repatriation in the History of Habsburg and Hungarian Archives." Hungarian Cultural Studies. e-Journal of the American Hungarian Educators Association, Volume 11 (2018) DOI:

The current paper sets out to examine this goal of the MKP. Just as diaspora individuals, such as Hungarian-Americans, have a dual identity, these archives are of value both to the host country and to Hungary. I will therefore argue that better cooperation with potential repositories in the host country would be desirable. I will return to this in my conclusion, but for the proper understanding of this issue I believe it is necessary to explore the evolving mission and selfdefinition of the National Library and National Archives of Hungary.

We sometimes speak - rather imprecisely — of the archives of individuals. In the sense that they are the result of an individual's life activity, this is not quite wrong. More commonly, the papers of individuals end up in libraries. In fact, libraries and archives may compete for the papers of individuals. In the nineteenth century, the OSzK (then a part of the National Museum) and the Hungarian archives competed for the possession of Hungary's medieval documents. Were they records documenting the activity of the medieval Hungarian state, or precious artifacts collected by individuals, works of art? They were both.

The distinction between libraries and archives, and of the OSzK and National Archives, is also important because librarians and archivists are separately defined professions, with their own procedures and regulations. With all this in mind, let us turn to the history of the National Archives of Hungary. Archival institutions today, including those of Hungary, serve the needs of researchers seeking to understand the past. But that is not how they started. The records that were preserved and consulted by governments were most often those that recorded rights of property and privilege, and archives were places where a lot of them could be found. In 1723 the Országgyülés ['Diet'] passed Law XLV to establish a Magyar Országos Levéltár or MOL ['The National Archives of Hungary'] for the purpose of supporting its efforts to defend the rights of the country in the rights of its dominant body, the nobility and its Diet. For more than a century, this archive had very restricted access and was principally used by the Diet and the country's Palatine, or viceroy, and only exceptionally by historians (Lakos 2006: 28-77).

Only in the form established after the Austro-Hungarian Compromise of 1867 did the MOL truly become the archive of the entire country, preserving many other records besides those of the Diet, as well as an institution for historical research. The acquisitions program of the MOL focused on the records of state administration within the territory of Hungary, primarily as large collections residing in government offices, but sometimes as individual documents or smaller artificial collections that had made their way into private ownership or foreign repositories. Still operating as a part of the National Museum, the OSzK managed already in the thirty years up to 1900 to acquire the papers of various members of the anti-Habsburg emigration (Kossuth and Türr) which only after 1945 came to the MOL as part of its Post-1945 Collection, the R Section (National Archives of Hungary 2018).

In discussions between the MOL and its Austro-Hungarian counterparts in Vienna about the appropriate owner of certain records, opposing principles came into play: the pertinence (subject matter) vs. the provenance (the original creator, or original order) of the records. Librarians catalog and shelve books according to their subject matter, but archival records cannot receive individual cataloging attention and are most useful to historians if their administrative context is preserved. The Hungarians tried, and failed, to secure Austrian agreement to the separation from Vienna's Hofkammerarchiv ['Court Chamber Archives'] of those records pertaining to Hungary or created on Hungarian territory as part of the operation of the imperial administration. The decision was based not simply on the assertion of Austrian interests vs. those 
Niessen, James P. "Heritage and Repatriation in the History of Habsburg and Hungarian Archives." Hungarian Cultural Studies. e-Journal of the American Hungarian Educators Association, Volume 11 (2018) DOI:

of Hungary, but rather on the philosophical position that provenance (since the imperial state was the creator of the records) took precedence over the records' Hungarian subject matter.

By the beginning of the twentieth century, the principle of provenance had attained widespread acceptance in the archival profession. This did not prevent the outbreak of a fresh international dispute over its application to the archives of the Austro-Hungarian Monarchy after 1918. After many past wars, archives had changed hands along with their territory. This was more complicated in those cases where the ceded territory had been part of a larger administrative unit. The peace treaties signed by Austria and Hungary in St. Germain and Trianon, respectively, recognized the principle of provenance. But in practice several of Austria's successor states were, in separate bilateral treaties, able to secure the separation of selected records of Austrian ministerial archives after 1888 based on their pertinence to Bohemia, Moravia, Galicia, and northern Italy. Such records went to the new national archives in these countries. No such concessions were forced upon Hungary, so that the records of government ministries that pertain to Slovakia and Transylvania are complete up to 1918 with the exception of those that were destroyed by military action in World War II and 1956. Furthermore, although the Transylvanian Court Chancery and Gubernium records pertain exclusively to territory now in Romania, they remained in the MOL where they had been moved after the Compromise (Niessen 2007).

Let us turn now to the documentation of those Hungarians who emigrated to the New World. These might be records created by the emigrants themselves or by their organizations; in these cases, they were of Hungarian-American provenance. Then there are the records of governments and organizations, many of which are of Hungarian pertinence but not provenance. In documenting the Austrian and Hungarian archives about Pennsylvania's Hungarian immigrants before World War I, Kristina Poznan notes that they "lived transnational lives by becoming active citizens in Pennsylvania and the United States more broadly but also maintaining close ties to their homelands" (Poznan 2016: 417-19). Of course, much parallel documentation about the immigrants may be found in the archives of American institutions. But the easy transnational communication that Poznan describes changed after 1914. The fact that the US and Hungary were on opposite sides in two world wars, and then the Cold War, greatly lessened transnational contacts. The Hungarian communities in the United States came in various waves of different social character and political orientation - thereby weakening attempts to build national organizations and isolating the Hungarian communities. The survival of such organizations' records was hit or miss.

In the interwar period, Hungarian Americans Charles Feleky and Edmund Vasváry built eclectic collections of books, periodicals, and clippings. After the next war, the Bethlen Archives in Ligonier, Pennsylvania and the American Hungarian Foundation in New Brunswick, New Jersey assembled varied collections of church records, personal papers, and Hungarian American books and periodicals. American academic and federal institutions came to acquire the personal papers of many Hungarian American individuals (Niessen 2013). The OSzK developed a new and growing interest in American diaspora collections after 1970, creating inventories and funding documentation trips to the U.S., making generous use of Fulbright grants. The work of András Csillag, Ilona Kovács, and Nóra Deák to create the finding aid for the Bethlen Collection (which had been deposited in New Brunswick) is one of the lasting results of this trend (Kovács 2013, Deák 2013). 
Niessen, James P. "Heritage and Repatriation in the History of Habsburg and Hungarian Archives." Hungarian Cultural Studies. e-Journal of the American Hungarian Educators Association, Volume 11 (2018) DOI:

The interest of the MOL in American Hungarica documentation is more recent than that of the OSzK. During the Cold War the archives focused on Hungarica archives in the neighboring countries, making documentation and microfilming trips in 326 foreign archives between 1952 and 1992 (Kollega 1992). The expense of this microfilming operation seems to have been out of proportion to its value to researchers, but valued as an insurance policy for the preservation of the material. At some point in the 1960s the National Center for Archives, to which the MOL reported, began work on a legal definition of archival Hungarica that was promulgated in 1971. Hungarica documentation became an explicit task of the MOL in 1979 (Bakó 2017; Lakos 2006: 411-12, 419). The MOL compiled three reports on archival Hungarica in the US already before the fall of the socialist regime that remain unpublished to this day. (Viszket and Zentai 2005: 50)

Hungary's Archives Law (LXVI) of 1995 includes among the archives' collecting responsibilities archival material existing abroad that pertains to Hungary or Hungarians (Arany 2016: 16). Government support for Hungarica documentation has grown dramatically since the election of the second Orbán government in 2010, which declared in its new fundamental law a commitment to support the survival and development of Hungarian communities everywhere (Hungary 2011). In May 2012 the so-called Hungarica Law, XXX, defined distinctively Hungarian products and objects, including archives. On October 1, 2012 the Hungarian National Archives ['Magyar Nemzeti Levéltár'] (MNL) arose through the creation of a common organization for the MOL and the country's county archives. The operating statute, enacted in December of that year, states that the basis for the new organization was Law XLV of 1723, which stipulated that the MOL should include the county archives.

It is clear that the archives of the country were charged, well before 2012, with the documentation of the nation's life far beyond the borders of the country. The new status of the MNL heightened the level of interest in Hungarica-collecting by identifying as one of the responsibilities of the MOL "the public documentation of archival Hungarica materials, the direction, organization, and publication of Hungarica research (Hungarian National Archives 2012: 19). According to Béla Nóvé, a month after the promulgation of the statute the MNL organized a Consulting Committee for Exploring and Rescuing Hungarian Documents in the West, which called for "broad national and international efforts to explore and save the written heritage of the Hungarian Western diaspora" (Nové 2013: 273). This consultation provides the context for the surprising invitation I received to make a presentation to the opening plenary session of the annual meeting of the Association of Hungarian Archivists in Esztergom in June of 2013. The growing interest of the Hungarian government in Hungarica documentation was also evident in the presentations at the Seventh World Congress of Hungarian Librarians at the OSzK, to which, as in the past, I received an invitation as one of the handful of American librarians engaged in Hungarian Studies. This presentation also focused on Hungarica collections in the US, but also more specifically on Rutgers and its digitized collection of papers about Camp Kilmer. Both PowerPoints are now available online (Niessen 2013a, Niessen 2013b).

My talk in Esztergom was more substantial than the presentation at the OSzK and to a much larger audience. The organizers asked for a copy of my PowerPoint, indicating they planned to put all the talks online. I was disappointed when this did not take place, because there were many very interesting presentations. The website of the Association of Hungarian Archivists did place online a four-page summary of the conference, dated September 25 (three 
Niessen, James P. "Heritage and Repatriation in the History of Habsburg and Hungarian Archives." Hungarian Cultural Studies. e-Journal of the American Hungarian Educators Association, Volume 11 (2018) DOI:

months after the conference) that is no longer accessible but was reprinted word for word in the society's journal (Boross et al. 2013). My talk had summarized the perilous financial state of the handful of significant Hungarian-American manuscript repositories, but placed more emphasis on the important holdings of American Hungarica manuscripts in academic, private, and federal institutions, like Columbia, the Immigration History Research Center, the Historical Society of Pennsylvania, the Hoover Institution, the Library of Congress and the National Archives. I emphasized the growing interest of researchers in the US in the study of the East European diaspora. The National Endowment for the Humanities funded a Summer Institute on this topic scheduled in the summer of 2014, for which we compiled a directory of relevant collections in the New York area that was published in the journal Slavic \& East European Information Resources at the end of 2013 ("Guide to East European Resources in the New York Metropolitan Area." 2013).

The summary of my talk in the report published in the society's journal creates a misleading impression because it has me stating that "in the discovery of these documents and in many cases their collecting together we are in the twenty-fourth hour because the change of generations the growing assimilation is accompanied by the destruction of the written material." In fact, I had emphasized the active interest of repositories and researchers in this material. It may be only a coincidence that the Diaspora Council proceeded to approve the MKP just two months after this summary was posted. At subsequent meetings of the Diaspora Council, books and manuscripts brought to Hungary by the MKP are displayed in cases for examination by the attendees.

The MNL only officially joined the Mikes program in 2015. The papers of New Jersey's Károly Nagy, a Rutgers University alumnus and long-time AHEA member, which were donated to the MNL by his widow, were displayed at the Diaspora Council meeting in November 2016. The career of Dr. Nagy and the arguments in his publications highlight the importance of American society and pluralistic democracy for the life of Hungarians in the diaspora. Thus, he was not only a Hungarian but also an American and a valuable contributor to the diversity of American society. Since the beginning of full MNL participation in the Mikes program a second notable archival acquisition has been the records of the Hungarian House of Toronto, registered in the MNL as OL P 2343. The description of this collection in the second volume of Hazatérö emlékeink notes that it had been offered to the National Archives of Canada, which declined it, but it appears it was never offered to the University of Toronto- which has a Hungarian Studies program and collections of long standing (Gárdonyi, ed. 2017). Owners may of course decide where to donate their materials. I suggest that it would be an appropriate professional courtesy for potential recipients in Hungary to advise donors of options of alternatives to the "repatriation" of these archives.

In consultation with fellow members of the US delegation to the Diaspora Council and the AHEA Board, I have discussed my concerns about the failure to communicate with repositories in the US about the Hungarica manuscript material (principally personal papers) that has been taken to Hungary. I spoke up at a plenary session of the Diaspora Council, I visited the office of MKP coordinator, Géza Gárdonyi, at Szentháromság Square, and I raised the issue again at the regional meeting of the Diaspora Council in Washington, DC in March 2017. My proposal is simple. I propose that libraries and archives in North America that have expressed an interest in knowing about these materials be informed when there is the offer to Hungary of a manuscript donation by residents of their geographic area. 
Niessen, James P. "Heritage and Repatriation in the History of Habsburg and Hungarian Archives." Hungarian Cultural Studies. e-Journal of the American Hungarian Educators Association, Volume 11 (2018) DOI:

\section{Works Cited}

Arany, Krisztina. 2016.“Levéltári ajándékozások a Mikes Kelemen Program keretében —a levéltári koordináció első évének tapasztalai" ["Archival Donations in the Framework of the Mikes Kelemen Program-The Experiences of the First Year of Archival Cooperation'] Hazatérö emlékinek, 16.

Bakó, Zsigmond. 2017. “A levéltár feldolgozási gyakorlata, a torontói levéltári hagyaték feldolgozása" ['The Practice of Archival Processing, The Processing of the Toronto Archival Legacy']. (Presentation at the Mikes Kelemen Program conference in Budapest, May 4, 2017).

Boross, István, István Hermann, and Balázs Somfai. 2013. "Beszámoló a Magyar Levéltarosok Egyesületének 2013. évi vándorgyüléséröl." Levéltári szemle 63, 2: 84-93.

Dányi Kaposváriné, Éva. 2016. “A Mikes Kelemen Program és a nemzeti könyvtár” ['The Mikes Kelemen Program and the National Library']. Hazatérő emlékeink: Tanulmányok a Julianus és Mikes Kelemen Programról. Budapest: Budapest: Bethlen Gábor Alapkezelö Zrt. 12-13.

Deák, Nóra. 2013. "American Hungarian Library Connections: Collecting, Inventorying, Preserving, and Sharing Hungarian Documents in the United States," Slavic \& East European Information Resources 14, 4: 267-72.

Gardonyi, Géza (ed.). 2016. Hazatérő emlékeink: Tanulmányok a Julianus és Mikes Kelemen Programról. ['Our Cultural Artifacts Returning Home: Studies on the Julianus and Mikes Kelemen Program']. Budapest: Budapest: Bethlen Gábor Alapkezelő Zrt. 2017. Hazatérö emlékeink II: Tanulmányok a Mikes Kelemen Programról. ['Our Keepsakes Returning Home II: Studies on the Mikes Kelemen Program']. Budapest: Budapest: Bethlen Gábor Alapkezelő Zrt.

"Guide to East European Resources in the New York Metropolitan Area." 2013. Slavic \& East European Information Resources, 14:4, 283-398, DOI: 10.1080/15228886.2013.853151

Hungary. 2011. Az alaptörvény. http://www.kormany.hu/hu/mo/az-alaptorveny (accessed May $30,2018)$

Kollega, István Tarsoly. 1992. "Levéltári hungarika kutatás" ['Archival Hungarica Research']. Levéltári szemle 42, 2: 40-52.

Kovács, Ilona. 2013. "The Hungarica Program of the National Széchényi Library (Budapest, Hungary)," Slavic \& East European Information Resources 14, 4: 259-66.

Lakos, János. 2006. A Magyar Országos Levéltár története ['The History of the Hungarian Archives of the Country']. Budapest: Magyar Országos Levéltár.

National Archives of Hungary. 2012. A Magyar Nemzeti Levéltár szervezeti és müködési szabályzata ['The Organizational and Operational Statutes of the Hungarian National Archives']. Budapest. Formerly online at http://mnl.gov.hu .

National Archives of Hungary. 2016. A Magyar Nemzeti Levéltár szervezeti és müködési szabályzata ['The Organizational and Operational Statutes of the Hungarian National Archives']. Budapest. http://mnl.gov.hu/kozadat/tevekenyseg_mukodes/szmsz.html (accessed May 30, 2018) 
Niessen, James P. "Heritage and Repatriation in the History of Habsburg and Hungarian Archives." Hungarian Cultural Studies. e-Journal of the American Hungarian Educators Association, Volume 11 (2018) DOI:

National Archives of Hungary. 2018. “1526 utáni gyüjtemény” ['Post-1526 Collection']. http://mnl.gov.hu/bal_menusor/hasznalat/kutatas/iratanyag_leirasa/1526_utani_gyujteme ny.html (accessed May 30, 2018)

Niessen, James P. 2007. "Records of Empire, Monarchy, or Nation? The Archival Heritage of the Habsburgs in Central Europe," Ab Imperio 3: 265-90. Online: http://dx.doi.org/doi:10.7282/T3GF0RX4 (accessed May 30, 2018).

Niessen, James P. 2013a. “Az Egyesűlt Államokban őrzött magyar vonatkozású elsődleges források" ['Primary Resources about Hungarians Preserved in the United States']. Esztergom, June 17, 2013, at http://dx.doi.org/doi:10.7282/T36T0Q38.

Niessen, James P. 2013b. "Hungarika-Gyüjtemények az USA-ban: Camp Kilmer és Rutgers" ['Hungarica Collections in the USA: Camp Kilmer and Rutgers']. Budapest, May 29, 2013, at http://vilagtalalkozo.oszk.hu/sites/vilagtalalkozo.oszk.hu/files/niessenjames.pdf

Niessen, James P. 2013c. "Documenting the American Heritage of the U.S.: Efforts at Home and Abroad," Slavic \& East European Information Resources 14, 4: 234-41 and http://dx.doi.org/doi:10.7282/T3F76G12 (accessed May 30, 2018).

Nóvé, Béla. 2013. "Perishing Papers, Vanishing Witnesses? The Future Fate of Hungarian Diaspora Collections," Slavic \& East European Information Resources 14, 4: 273-80.

Poznan, Kristina E. "Pennsylvania Migrants in the Austrian State Archives and Hungarian National Archives: Dual Repositories for Migrants from a [sic] Dual Monarchy," The Pennsylvania Magazine of History and Biography 140 (3): 417-19.

Viszket, Zoltán, and Katalin Zentai. 2005. "A hungarikakutatás és a Magyar Országos Levéltárban örzött hungarika-jelentés-gyüjtemény” ['Hungarica Research and the Collection of Hungarica Reports preserved in the Hungarian National Archives']. Levéltári szemle 55 (4): 41-57. 